REVISTA DE ESTUDIOS E INVESTIGACIÓN EN PSICOLOGÍA Y EDUCACIÓN

\title{
Teen resilience: the role of school and family connectedness
}

\section{Resiliencia en adolescentes: el papel de la conectividad con la escuela y familia}

Mercedes Gabriela Orozco-Solís (Di) https://orcid.org/0000-0002-0648-8233

Héctor Rubén Bravo-Andrade (D) https://orcid.org/0000-0002-0498-8410

Norma A. Ruvalcaba-Romero (Di) https://orcid.org/0000-0001-9209-8751

Departamento de Clínicas de la Salud Mental, Centro Universitario de Ciencias de la Salud Laura Nadhielii Alfaro-Beracoechea (iD) https://orcid.org/0000-0002-9857-7339

Departamento de Comunicación y Psicología, Centro Universitario de la Ciénega

Universidad de Guadalajara: https://www.udg.mx

Guadalajara, Jalisco - México

Correspondence concerning this article: Héctor Rubén Bravo-Andrade - ruben.bravo@academicos.udg.mx 


\begin{abstract}
The sense of connectedness with family and school is an element associated with the psychosocial development in adolescents, being a factor that can influence the way they respond against adversity and adjust to change. This study aimed to establish the predictive value of intrafamilial relationships and connectedness with school, teachers, and between students on resilience in Mexican high school adolescents. The sample consisted of 645 students ( $50.7 \%$ female), with an age range of 12 to 16 years old ( $M=$ 13.35, $S D=0.99$ ), from a public high school in the Guadalajara Metropolitan Area, México. Participants answered the Intrafamilial Relations Assessment Scale, the subscales of social connectedness with school and students of the MDS3 School Climate Survey, and the revised Resilience Questionnaire for Children and Adolescents. Using correlations and multiple linear regression analyzes, the results indicated moderate positive associations between the study variables and resilience. The higher coefficients were found in the correlation between intrafamilial relationships and resilience. In the predictive analysis, intrafamilial relationship, connectedness with school and between students, conserved its significance for predicting resilience, with family relationships maintaining the highest coefficient. Results suggest that the family environment is the main factor that shapes how adolescents cope with adversity. Limitations and practical implications are discussed. We conclude it is important to generate strategies that promote a higher adolescent connectedness with key environments for the development of protective factors such as resilience.
\end{abstract}

Keywords: resilience; social connectedness; adolescence; family; school

\title{
Resumen
}

El sentido de conexión con la familia y escuela es un elemento asociado con el desarrollo psicosocial de los adolescentes, siendo un factor que puede influir en su manera de responder a la adversidad y ajustarse a los cambios. Este estudio tuvo como objetivo establecer el valor predictivo de las relaciones intrafamiliares y la conexión con la escuela, los maestros y los estudiantes sobre la resiliencia en los adolescentes de secundaria. La muestra estuvo conformada por 645 estudiantes ( $50.7 \%$ mujeres), con un rango de edad de 12 a 16 años $(M=13.35, D T=0.99)$, de una escuela secundaria pública de México. Los participantes respondieron la Escala de Evaluación de Relaciones Intrafamiliares, las subescalas de conexión social con la escuela y los estudiantes de la Encuesta de Clima Escolar MDS3 y el Cuestionario de Resiliencia para Niños y Adolescentes revisado. Los resultados indicaron correlaciones positivas moderadas entre las variables de estudio y la resiliencia, siendo la más elevada la correlación entre relaciones intrafamiliares y resiliencia. En el análisis predictivo, la relación intrafamiliar, la conexión con la escuela y entre estudiantes, conservaron la significancia para predecir la resiliencia, manteniendo las relaciones familiares los coeficientes más altos. Los resultados sugieren que el entorno familiar es el factor principal que determina cómo los adolescentes afrontan la adversidad. Se discuten las limitaciones y las implicaciones prácticas. Concluimos que es importante generar estrategias que promuevan una mayor conexión del adolescente con los entornos que influyen en el desarrollo de factores protectores como la resiliencia.

Palabras clave: resiliencia; conectividad social; adolescencia; familia; escuela 
Adolescence is a phase in which maintaining a sense of connection and belonging with the individual's fundamental context becomes a central aspect to promote adequate psychosocial development (Steiner et al., 2019). From a bioecological perspective, the individual development is directly influenced by its interaction with different systems and the relationships between them (Bronfenbrenner, 1979). In general, family and school are considered two of the most important systems at this stage, within which the subject acquires the necessary elements for its socio-emotional development (Oldfield et al., 2016; Serrano \& Rodríguez, 2016).

Regarding family, teenagers who experience positive intrafamilial relationships, characterized by high cohesion and support, tend to have a better self-concept, social skills, and school performance, fewer socio-emotional problems, higher self-esteem and more resilience (Foster et al., 2017; Murillo-Casas et al., 2015; Preston et al., 2016; Tian et al., 2018). Likewise, in cases where adolescents are involved in negative situations (e.g., school victimization), high connectedness in the family serves as a protective factor to cope more adaptively with the experience (Duggins et al., 2016).

Moreover, the school environment acquires a particular relevance during adolescence, due to the increase interest in generating meaningful relationships with peers and adults outside the family nucleus (Loukas et al., 2016). The connection that the adolescent manages to establish with the school and the people in it, represents one of the main factors that influence academic success and socio-emotional development (Ricard \& Pelletier, 2016). In particular, relationships with peers and teachers characterized by affection, acceptance, and support can serve as important protective factors against academic, behavioral and mental health problems (Arora et al., 2017; Cyrian et al., 2016; Strati et al., 2017). Also, as Pitzer and Skinner (2016) mentions, students who feel connected to school are more likely to use adaptive strategies to face difficult situations and stay motivated to solve them.

Therefore, the connectedness established in the family and school represents an important factor for the generation of psychological resources involve in the response against adversity in adolescents, that is, the resilience (Murphy \& McKenzie, 2016; Stavrou \& Kourkoutas, 2017). Resilience is a dynamic process through which personal and contextual factors interact to allow the individual to successfully cope and adapt to adverse events (Friborg et al., 2003). In adolescence, resilience associates with better academic performance, positive interpersonal relationships, fewer emotional problems, more satisfying quality of life, better socio-emotional skills, among other results (Molero et al., 2019; Ruvalcaba et al., 2019; SimónSaiz et al., 2018; Villalta et al., 2017). Resilience is considered a dynamic process that involves 
the interaction between internal and external factors that influence the adaptation process of the individual to adversity (Hjemdal et al., 2006). Even when there is no consent about the elements involved in a resilience response, some authors agree that it usually includes the presence of factors from three main components: (a) personal characteristics, (b) family cohesion, and (c) social support from outside the family (Hjemdal et al., 2012; Limonero et al., 2012).

The influence that intrafamilial relationships and a sense of connection with the school environment have on the development of resilience in adolescents is a topic that has been investigated in some studies. Regarding the family, Dias and Cadime (2017) stated that family ties characterized with constant support and positive modeling of how to respond to adversity, promote greater resilience. In cases where the adolescent experiences a condition of vulnerability or a specific adverse event, the quality of communication, support, and family cohesion are factors that increase resilience and decrease socio-emotional changes (Acuña \& Kataoka, 2017; Agustini et al., 2019; Ross et al., 2017).

Regarding the school environment, institutions that establish high academic and social expectations, care relationships, accompanied by opportunities to actively participate in the educational environment, tend to promote greater resilience in students (Aldrige et al., 2015; Yablón, 2015). Regarding social connectedness, the relationships established with peers, teachers, and the school itself are elements that influence resilience, providing a system of care, support, and promotion of skills necessary to face adversities (Aldridge et al., 2015; Kuperminc et al., 2019; Mirza \& Arif, 2018).

Although the bond with peers at school is an element that influences psychosocial development of adolescents (Heinsch et al., 2019), this variable has not been commonly studied in direct relation to resilience, observing more attention to the analysis of the influence of connection with peers in a general context. Several investigations have found that peer support is a significant predictor of resilience, being associated with the reduction of socioemotional problems derived from adverse situations (Foster et al., 2017; van Harmelen et al., 2016; Oldfield et al., 2018; Villalobos-Parada et al., 2016).

We can conclude that a sense of connectedness to family and significant persons in the educational environment is an element related to a resilient response against adversity during adolescence. However, most of the existing studies have explored this influence in adolescents facing adverse situation in life (e.g. diseases, bullying, violence, etc), finding only few studies conducted on adolescents who do not face specific problematic situations at home or school. 
This situation limits the possibilities to identify the familial and school factors that can influence resilience in the general adolescent population.

Also, even though it is reported that adolescent's connection to family and school jointly influence resilience, most of the studies that address the interaction between these variables tend to explore only some components in a segmented way. Considering this, we intended to analyze from an integrated perspective, the influence that family relationships and different variables of school connectedness have on adolescent's resilience. The integrated analysis of the relationship between these variables will make it possible to identify the components that generate the greatest influence on this psychological resource. Therefore, the objective of this research was to establish the predictive value of intrafamilial relationships and connectedness with school, teachers, and students on resilience in Mexican high school adolescents.

\section{Method}

\section{Participants}

The final sample consisted of 645 students selected by convenience from two middle schools located in the Metropolitan Area of Guadalajara, Mexico.

The age range was 12 to 16 years ( $M=13.35, S D=0.99,50.7 \%$ female). The $54.7 \%$ of the students went to school in the morning shift and the rest belonged to the afternoon shift.

\section{Instruments}

Resilience. Resilience was measured through the total score of the Resilience Questionnaire for Children and Adolescents (González-Arratia, 2016) in its revised version for Mexican population ( $\alpha=.85$; Bravo-Andrade et al., 2019). The 18 items were anchored on a Likert scale with five response options ranging from never to always. The instrument has a four-dimension structure (introspection, empathy, problem solving and external protective factors) and a total score, which was the only element considered in the analysis. The alpha values in all the measurement instruments applied were $>.70$, which are considered representative of an adequate internal consistency in all the measurement instruments applied (Celina \& Campo, 2005).

Intrafamilial relations. We applied the brief version of the Intrafamily Relations Assessment Scale (IRAS; Rivera \& Andrade, 2010; $\alpha=.81$ ), consisting of 12 items with five response options ranging from totally disagree to totally agree. The instrument was developed for Mexican population and consist of three dimensions: union and support, expression and difficulties. The instrument allows a total score, which was used for the present study. 
School connectedness. To evaluate the school connectedness variables, two subscales of the version for students of the MDS3 School Climate Survey were applied, adapted for Mexican population (Shkula et al., 2019). The school connectedness subscale $(\alpha=.81$ ), which has four items that address the sense of pride and satisfaction that is experienced towards the school (e.g., I enjoy learning in this school); and the connection between students subscale $(\alpha=.83)$, which has five items that include aspects related to perceptions of trust, support, and connection with peers (e.g., In this school, students help each other). The two subscales have response options on a five-point Likert scale, ranging from strongly disagree to strongly agree. The subscales were coded so higher scores indicate a greater sense of connectedness.

\section{Procedure}

After obtaining a signed informed consent by school authorities, the parents were informed that schools were conducting this research. The voluntary nature of the students' participation and the confidentiality of the information was made explicit to parents and students. The instruments were applied in the morning and afternoon shift, including all the participants present at the moment of data collection with the only criteria of being actively enrolled at the school.

The participants provided informant assent previous to the data collection, the instruments were applied in the classrooms during school hours by psychology students previously trained in survey application. Considering the data collection was going to be conducted anonymously, we only include measurement instruments that evaluated the variables from a positive perspective, more focused in the identification of protective factors.

\section{Data Analysis}

Although no statistical normality was found using the Kolmogorov-Smirnov test, the asymmetry and kurtosis statistics $< \pm 2$ are indicative of a distribution close to normal, therefore the chosen statistical procedures were parametric (Abad et al., 2011). Descriptive statistics, reliability indices, comparisons of means with the Student's t-test, Pearson product-moment correlations, and multiple linear regression analyzes were established. To measure effect size and statistical power, the G*Power v3 program was used. For the rest of the analysis, we used IBM SPSS V.25.

To examine the assumptions required for multiple linear regression, we performed the following analyzes: a) Linearity, we analyzed the trend towards linearity between the variables in scatter diagrams. b) Homoscedasticity, the Levene test corroborated the equality of variances 
for the dependent variable: resilience $F(643)=3.110 p=.078$. The graphs of the residuals from the regressions were examined, where no association patterns were observed. c) No autocorrelation. Even when the no autocorrelation criteria was not met (Durbin-Watson $=1.14$ ), the value obtained was near of the statistical standard and considering the rest of the assumptions were fulfilled, we considered adequate to continue with the analysis. d) Noncollinearity. The scores of the indicator of variance inflation factors (VIF), as well as of tolerance, were close to 1 . The condition indices were kept below 30 , with variance proportions that did not overlap.

\section{Results}

Table 1 shows the descriptive statistics, where all the study variables were above the theoretical mean.

\section{Table 1}

Descriptive statistics and correlations of observed variables $(N=645)$

\begin{tabular}{lcccccccccc}
\hline Variable & $M$ & $S D$ & Min & Max & $K-S$ & Skew & Kurtosis & \multicolumn{3}{c}{ Correlation analysis } \\
\hline $\begin{array}{l}\text { 1. Resilience } \\
\begin{array}{l}\text { 2. Intrafamilial } \\
\text { relationships }\end{array}\end{array}$ & 70.16 & 10.91 & 18 & 90 & $.10^{* * *}$ & -0.72 & 0.43 & - & 2 & 3 \\
$\begin{array}{l}\text { 3. Connectedness } \\
\text { between students }\end{array}$ & 14.05 & 8.43 & 12 & 60 & $.06^{* * *}$ & -0.43 & -0.15 & $.46^{* *}$ & - \\
$\begin{array}{l}\text { 4. Connectedness } \\
\text { with school }\end{array}$ & 12.81 & 2.56 & 4 & 16 & $.13^{* * *}$ & -0.88 & 0.95 & $.41^{* *}$ & $.35^{* *}$ & $.52^{* *}$ \\
\hline
\end{tabular}

$* * p<.01 ; * * p<.001$

A comparison of means by sex was carried out using the Student's $t$-test for independent samples. The results showed that there were no differences in any of the variables. The matrix of bivariate correlations is included in Table 1. All the associations were positive and statistically significant at a level of $<.01$. The magnitude was low to moderate. The largest associations were found between the variable Resilience with Intrafamilial Relations and Connectedness with the school. As expected, the correlation of Connectedness between students and Connectedness with school was relatively high, because both are part of the same instrument.

We carried out a hierarchical multiple linear regression analysis, which initially included the variables Connectedness with school and Connectedness between students, explaining $20 \%$ of the variance (Table 2). In the second model, the variable Intrafamilial Relations was included, reaching $29 \%$ of the variance. An increase in the size of the effect was obtained, positioning it 
as high, and the model showed high statistical power. The variable with higher predictive coefficient was intrafamiliar relationships, followed by connectedness between students.

\section{Table 2}

Multiple linear regression analysis with Resilience as dependent variable $(N=645)$

\begin{tabular}{lcccccc}
\hline Variables & $R^{2}$ adjusted & $F(d f)$ & $\beta$ & $t$ & $f^{2}$ & $1-\beta$ \\
\hline Model 1 & .19 & $7588.852(2,642)^{* *}$ & & & 0.24 & 1 \\
Connectedness with school & & & .19 & $4.54^{* *}$ & & \\
Connectedness between & & & .31 & $7.56^{* * *}$ & & \\
students & & & & & & \\
\hline Model 2 & .29 & $7628.018(3,641)^{* *}$ & & & 0.40 & 1 \\
Connectedness with school & & & .13 & $3.46^{* *}$ & & \\
Connectedness between & & & .23 & $5.58^{* *}$ & & \\
students & & & .34 & $9.58^{* * *}$ & & \\
Intrafamilial relationships & & & & & & \\
\hline
\end{tabular}

${ }^{* *} p<.01 ;{ }^{* * *} p<.001$

\section{Discussion}

The purpose of this investigation was to analyze the predictive value of intrafamilial relationships, connectedness with school and peers over Resilience in Mexican adolescents. An important contribution of this study was to explore the interaction between these variables in a general adolescent population, considering that previous research has analyzed this relationship in depth with individuals who face specific difficulties (Acuña \& Kataoka, 2017; Agustini et al., 2019; Villalobos-Parada et al., 2016; Yablón, 2019). In the results, we found that the quality of the connection that is perceived with these environments also maintains a significant influence over the resilience of adolescents in the general population, identifying that family is one of the systems with greatest influence.

Initially, the correlations between the study variables obtained low to moderate coefficients, finding the highest values in the associations of Resilience with Intrafamilial Relationships and Connectedness with school. This result coincides with the mentioned in different studies where it is reported that a sense of connectedness with family and school are factors associated with resilience in adolescents (Aldrige et al., 2015; Dias \& Cadime, 2017; Ross et al., 2017). This is relevant because resilience is a process that influences how adolescents make decisions, solve problems and face difficulties, representing an important protective factor against different problems (Molero et al., 2019; Simón-Saiz et al., 2018).

Regarding the results of the linear regression, the final model indicates that Intrafamilial Relationships, Connectedness with school, and with peers maintained a predictive power of $29 \%$ 
of the variance observed in resilience. Intrafamilial relationships emerged as the variable with the highest predictive value, corresponding with previous studies which mentioned that elements derived from a positive family dynamic tend to promote higher levels of resilience and lower negative results derived from exposure to adverse events (Agustini et al., 2019; Oldfield et al., 2016; Ross et al., 2017). As mentioned by Dias and Cadime (2017), the family environment shapes how the adolescent understands adversity, providing a key context for developing effective coping skills and obtaining the necessary support to face adverse events. Therefore, it is important to continue analyzing the role that specific elements of the family climate (e.g., values, spirituality, communication, etc.) can have on the resilience of general adolescent populations, seeking to determine the variables that need to be considered in future interventions.

The components of Connectedness with the school and between students also remained significance in predicting resilience in adolescents. As mentioned by some authors, the sense of belonging and connection that a student has with school and peers are elements that influence how the adolescent faces difficult situations (Aldridge et al., 2015; Heinsch et al., 2019; Mirza \& Arif, 2018). Regarding this result, it is noteworthy that the connection with students maintained a higher prediction coefficient compared to the connection with school. Previous studies have related the support of peers at school as an important mediator in adverse situations such as bullying, constituting a factor that increases resilience and reduces the socio-emotional consequences of this phenomenon (Dudugins et al., 2016; van Harmelen et al., 2016; Worsley et al., 2019). However, few investigations had explored the specific role that the connection between students have on resilience, being necessary to continue delimiting the components of peer interaction that are particular to the school environment and that influence resilience.

Concerning the predictive value that Connectedness with school and between students maintained, it is remarkable that, by including Intrafamilial relationships in the second model, the overall predictive strength increased; however, the prediction coefficients of the first two variables decreased. This result might be related to the reported by other authors who pointed out that, even though the connection with school and peers are elements that influence resilience and other socio-emotional competences, the family maintains a greater weight on the development of these psychological resources (Dias \& Cadime, 2017; García \& Paino, 2017; Moore et al., 2018; Oldfield et al., 2016). Also, some studies reported that the protective role that school or peer connectedness can have on resilience seems to be mediated by the quality of intrafamilial relationships (Murphy \& McKenzie, 2016, Olfield et al., 2018). From a bioecological perspective it is important to analyze, not only the influence that these systems have separately, but also from an integrated approach. 
On the interaction of these variables, Murphy and McKenzie (2016) found that school connectedness was a protective factor against the negative influence that poor-quality familial relationships can have on the development of resilience. In other words, students who have a low connection with their family, but maintain a feeling of belonging and connection with the school environment, have greater possibilities of developing psychological resources such as resilience. Regarding the connection with students, when an adolescent experiences positive family interactions, the connection with peers is positioned as a factor that can favor the development of psychological resources to face adversity (Moore et al., 2018; Oldfield et al., 2018). In cases with negative family interactions, the connection with peers can become a risk factor for the development of socio-emotional problems. Therefore, it is necessary to continue analyzing the mediating role that school and student connectedness might have in the interaction between intrafamilial relationships and resilience.

Based on the mentioned so far, it is possible to conclude that the sense of connectedness to family and school are elements that influence the development of protective resources such as resilience. Therefore, it is important to conduct future research oriented to the promotion of stronger links between the adolescents and their key environments, being also necessary to strengthen the links between these systems from an integrated perspective (Bronfenbrenner, 1979). The development of stronger links between family and school can promote that creation of environments that provide more opportunities to stablish connections and increase the sense of belonging for the adolescent. Considering this, it is necessary to continue analyzing the factors of the family and school environment that can interact positively to promote the development of psychological resources such as Resilience.

\section{Limitations and practical implications}

The limitations of this study include the method of collecting information through selfreports, recommending the development of future research that includes different evaluation methods (e.g., observational, measurement instruments responded by teachers/parents/, etc). In addition to the above, even when we included a representative sample, the sample selection method used limits the possibility of establishing generalizations based on the results obtained, so it is important to carry out studies that include larger samples, from different contexts and selected using random methods.

Despite the limitations mentioned above, it is important to note that this study offers relevant information for families, professionals, and educational authorities involved in the process of generating contexts that promote a positive development in adolescents. Although 
the results from the predictive analysis are moderated, they provide relevant information that should be taken into consideration in future research. It would be important to continue exploring other family and school variables that might be interacting with the connectedness in the prediction of resilience and other protective factors.

One of the practical implications of this research was to be able to analyze the influence that connection with family and school environment has on teenager students from the general population. This allows us to get a sense of the predictive value of these components and identify the variables that need to be included in future studies to analyze the factors that promote a more successful coping with adversities in adolescence.

Moreover, the results of this research made it possible to identify that the connection between students -a variable not commonly included in previous studies- is an element that influences resilience with greater importance than school connection. This finding highlights the importance of continuing to analyze those components of peer interaction that are specific to the school environment, which can have a significant influence on the development of different psychological resources.

Finally, it would be important to consider the results from this research for the development of intervention strategies at family and school level. As several research has pointed out, it is necessary to develop practical mechanisms that promote a stronger connection with key environments for adolescents, supporting the creation of safe spaces oriented to wellbeing and mental health.

\section{Conflict of Interest}

The authors declare that the research was conducted in the absence of any commercial or financial relationships that could be construed as a potential conflict of interest.

\section{Author Contributions}

$\mathrm{GO}$, and HB contributed to the conception and design of the study. GO organized the database. HB performed the statistical analysis. NR wrote the first draft of the manuscript. GO, HB, NR, and LA wrote sections of the manuscript. All authors contributed to manuscript revision, read, and approved the submitted version.

\section{Data Availability Statement}

The raw database that supports these study conclusions will be made available to any qualified researcher upon request. 


\section{References}

ABAD, Francisco; OLEA, Julio; PONSODA, Vicente., \& GARCÍA, Carmen (2011). Medición en ciencias sociales y de la salud. Madrid: Síntesis.

ACUÑA, Alejandra; \& KATAOKA Sheryl (2017). Family Communication Styles and Resilience among Adolescents. Social Work, 62(3), 261-269. https://doi.org/10.1093/sw/swx017

AGUSTINI, Nur; NURHAENI, Nani; PUJASARI, Hening; ABIDIN, Elni; LESTARI, Ayu; \& KURNIAWATI, Amy (2019). Family Support towards Resilience in Adolescents with Type I Diabetes: A Preliminary Study in Indonesia. Asian/Pacific Island Nursing Journal, 4(2), 66-71. https://doi.org/10.31372/20190402.1028

ALDRIDGE, Jill; FRASER, Barry; FOZDAR, Farida; ALA'I, Kate; EARNEST, Jaya; \& AFARI, Ernest (2016). Students' perceptions of school climate as determinants of wellbeing, resilience, and identity. Improving Schools, 19(1), 5-26. https://doi.org/10.1177/1365480215612616

ARORA, Prema; WHEELER, Lorey; FISHER, Sycarah; \& BARNES, Jessica (2017). A prospective examination of anxiety as a predictor of depressive symptoms among Asian American early adolescent youth: The role of parent, peer, and teacher support and school engagement. Cultural Diversity and Ethnic Minority Psychology, 23(4), 541-550. https://doi.org/10.1037/cdp0000168

BRAVO-ANDRADE, Héctor Rubén; GONZÁLEZ-BETANZOS, Fabiola; RUVALCABA-ROMERO, Norma Alicia; LÓPEZ-PEÑALOZA, Judith; \& OROZCO-SOLÍS, Mercedes Gabriela (2019). Propiedades psicométricas del cuestionario de resiliencia para niños y adolescentes en estudiantes mexicanos de bachillerato. Acta Colombiana de Psicología, 22(2), 292-305. https://doi.org/10.14718/ACP.2019.22.2.14

BRONFENBRENNER, Urie (1987). La ecología del desarrollo humano. Barcelona: Paidós.

CELINA, Heidi., \& CAMPO, Adalberto (2005). Aproximación al uso del coeficiente alfa de Cronbach. Revista Colombiana de Psiquiatría, 34(4), 572-580. Disponible en: http://www.redalyc.org/articulo.oa?id=80634409

CYRIAN, Coyle; BRAMHAM, Jessica; DUNDON, Neil; MOYNIHAN, Manus; \& CARR, Alan (2016). Exploring the Positive Impact of Peers on Adolescent Substance Misuse. Journal of Child and Adolescent Substance Abuse, 25(2), 134-143. https://doi.org/10.1080/1067828X. 2014.896761

DIAS, Paulo Cesar; \& CADIME, Irene (2017). Protective factors and resilience in adolescents: The mediating role of self-regulation. Psicología Educativa, 23(1), 37-43. https://doi.org/ 10.1016/j.pse.2016.09.003 
DUGGINS, Shaun; KUPERMINC, Gabriel; HENRICH, Christopher; SMALLS-GLOVER, Clara; \& PERILLA, Julia (2015). Aggression among adolescent victims of school bullying: Protective roles of family and school connectedness. Psychology of Violence, 6(2), 205-211. https://doi.org/10.1037/a0039439

FOSTER, Cynthia Ewell; HORWITZ, Adam; THOMAS, Alvin; OPPERMAN, Kiel; GIPSON, Polly; BURNSIDE, Amanda; STONE, Deborah; \& KING, Cheryl (2017). Connectedness to family, school, peers, and community in socially vulnerable adolescents. Children and Youth Services Review, 81(10), 321-331. https://doi.org/10.1016/j.childyouth.2017.08.011

FRIBORG, Oddgeir; HJEMDAL, Odin; ROSENVINGE, Jan; \& MARTINUSSEN, Monica (2003). A new rating scale for adult resilience: What are the central protective resources behind healthy adjustment? International Journal of Methods in Psychiatric Research, 12, 65-76. https://doi.org/10.1002/mpr.143

GARCÍA, María Luisa. \& PAINO, Natalia (2017). Coordinación educativa escuela-familia. Dificultades y soluciones. Revista de Estudios e Investigación en Psicología y Educación, Extr(5), 75-78. https://doi.org/10.17979/reipe.2017.0.05.2330

GONZÁLEZ-ARRATIA, Norma Ivonne (2016). Resiliencia y personalidad en niños y adolescentes. Cómo desarrollarse en tiempos de crisis. Universidad Autónoma del Estado de México/ Ediciones Eón.

HEINSCH, Milena; AGLLIAS, Kylie; SAMPSON, Dara; HOWARD, Amanda; BLAKEMORE, Tamara; \& COOTES, Hannah (2019). Peer connectedness during the transition to secondary school: A collaborative opportunity for education and social work. The Australian Educational Researcher, 47, 339-356. https://doi.org/10.1007/s13384-019-00335-1

HJEMDAL, Odin; FRIBORG, Oddgeir; \& STILES. Tore (2012). Resilience is a good predictor of hopelessness even after controlling for stressful life events, mood, and personality. Scandinavian Journal of Psychology, 53(2), 178-180. https://doi.org/10.1111/j.14679450.2011.00928.x

HJEMDAL, Odin; FRIBORG, Oddgeir; STILES, Tore; ROSENVINGE, Jan; \& MARTINUSSEN, Monica (2006). Resilience predicting psychiatric symptoms: A prospective study of protective factors and their role in adjustment to stressful life events. Clinical Psychology and Psychotherapy, 13, 194-201. https://doi.org/10.1002/cpp.488

KUPERMINC, Gabriel; CHAN, Wing Yi; HALE, Katherine; JOSEPH, Hannah; \& DELBASSO, Claudia (2019). The role of school-based group mentoring in promoting resilience among vulnerable high school students. American Journal of Community Psychology, 65(1-2), 136-148. https://doi.org/10.1002/ajcp.12347 
LIMONERO, Joaquín; TOMÁS-SÁBADO, Joaquín; FERNÁNDEZ-CASTRO, Jordi; GÓMEZ-ROMERO, María José; \& ARDILLA-HERRERO, Amor (2012). Estrategias de afrontamiento resilientes y regulación emocional: Predictores de satisfacción con la vida. Psicología Conductual, 20(1), 183-196. Available in: https://www.behavioralpsycho.com/producto/estrategiasde-afrontamiento-resilientes-y-regulacion-emocional-predictores-de-satisfaccion-con-lavida/

LOUKAS, Alexandra; CANCE, Jessica; \& BATANOVA, Milena (2016). Trajectories of school connectedness across the middle school years: examining the Roles of adolescents' internalizing and externalizing problems. Youth and Society, 48(4), 557-576. https://doi. org/10.1177/0044118X13504419

MIRZA, Munawar S.; \& ARIF, Muhammad Irfan (2018). Fostering academic resilience of students at risk of failure at secondary school level. Journal of Behavioural Sciences, 28(1), 33-50. Available in: http://pu.edu.pk/home/journal/24/V_28_No_1_2018.html

MOLERO, María del Mar; PÉREZ-FUENTES, María del Carmen; BARRAGÁN, Ana Belén; DEL PINO, Rosa María; \& GÁZQUEZ, José Jesús (2019). Analysis of the Relationship between Emotional Intelligence, Resilience, and Family Functioning in Adolescents' Sustainable Use of Alcohol and Tobacco. Sustainability, 11(10), 1-17. https://doi.org/10.3390/su11102954

MOORE, Graham; COX, Rebecca; EVANS, Rhiannon; HALLINGBERG, Britt; HAWKINS, Jemma; LITTLECOTT, Hannah; LONG, Sara; \& MURPHY, Simon (2018). School, Peer and Family Relationships and Adolescent Substance Use, Subjective Wellbeing, and Mental Health Symptoms in Wales: A Cross-Sectional Study. Child Indicators Research, 11, 1951-1965. https://doi.org/10.1007/s12187-017-9524-1

MURILLO-CASAS, Ánxela; PRIEGUE-CAAMAÑO, Diana; \& CAMBEIRO-LOURIDO, María do Carmen (2015). Una aproximación a los estilos educativos parentales como prácticas socializadoras. Revista de Estudios e Investigación en Psicología y Educación, Extr.(05), 083-087. https://doi.org/10.17979/reipe.2015.0.05.274

MURPHY, Emma; \& MCKENZIE, Vicki (2016). The Impact of Family Functioning and School Connectedness on Preadolescent Sense of Mastery. Journal of Psychologists and Counsellors in Schools, 26(1), 35-51. https://doi.org/10.1017/jgc.2015.17

OLDFIELD, Jeremy; HUMPHREY, Neil; \& HEBRON, Judith (2016). The role of parental and peer attachment relationships and school connectedness in predicting adolescent mental health outcomes. Child and Adolescent Mental Health, 21(1), 21-29. https://doi.org/ 10.1111/camh.12108 
OLDFIELD, Jeremy; STEVENSON, Andrew; ORTIZ, Emily; \& HALEY, Bethany (2018). Promoting or suppressing resilience to mental health outcomes in at-risk young people: The role of parental and peer attachment and school connectedness. Journal of Adolescence, 64, 1322. https://doi.org/10.1016/j.adolescence.2018.01.002

PITZER, Jennifer; \& SKINNER, Ellen (2017). Predictors of changes in students' motivational resilience over the school year: The roles of teacher support, self-appraisals, and emotional reactivity. International Journal of Behavioral Development, 41, 15-29. https://doi.org/10.1177/0165025416642051

PRESTON, Kathleen; GOTTFRIED, Allen; OLIVER, Pamella; GOTTFRIED, Adele; DELANY, Danielle; \& IBRAHIM, Sirena (2016). Positive family relationships: Longitudinal network of relations. Journal of Family Psychology, 30(7), 875-885. https://doi.org/10.1037/fam0000243

RICARD, Nathalie; \& PELLETIER, Luc (2016). Dropping out of high school: The role of parent and teacher self-determination support, reciprocal friendships, and academic motivation. Contemporary Educational Psychology, 44(45), 32-40. https://doi.org/10.1016/j.ced psych.2015.12.003

RIVERA, María Elena; \& ANDRADE, Patricia (2010). Escala de Evaluación de las Relaciones Intrafamiliares (E.R.I.). UARICHA Revista de Psicología, 7(14), 12-29. Available in: http://www.revistauaricha.umich.mx/ojs_uaricha/index.php/urp/issue/view/40

ROSS, Alexandra; SIMONS, Laura; FEINSTEIN, Amanda; YOON, Isabel; \& BHANDARI, Rashmi (2017). Social risk and resilience factors in adolescent chronic pain: Examining the role of parents and peers. Journal of Pediatric Psychology, 43(3), 303-313. https://doi.org/10.1093/jpepsy/jsx118

RUVALCABA, Norma; GALLEGOS, Julia; OROZCO, Mercedes; \& BRAVO, Héctor (2019). Validez predictiva de las competencias socioemocionales sobre la resiliencia en adolescentes mexicanos. Diversitas, Perspectivas en Psicología, 15(1), 87-99. https://doi.org/10.15332/ s1794-9998.2019.0001.07

SERRANO, Bianca; \& RODRÍGUEZ, Mónica (2016). Funcionalidad de la familia y su incidencia en el rendimiento académico en adolescentes. Didascalia: Didáctica y Educación, 7(1), 235255. http://revistas.ult.edu.cu/index.php/didascalia/article/view/469/468

SHUKLA, Kathan; WAASDORP, Tracy; LINDSTROM, Sarah; OROZCO, Mercedes Gabriela; NGUYEN, Amanda; COLUNGA, C; \& BRADSHAW, Catherine (2019). Does school climate mean the same thing in the United States as in Mexico? A focus on measurement invariance. Journal of Psychoeducational Assessment, 37(1), 55-68. https://doi.org/10. $1177 / 0734282917731459$ 
SIMÓN-SAIZ, María José; FUENTES-CHACÓN, Rosa María; Garrido-Abejar, Margarita; SERRANOPARRA, María Dolores; LARRAÑAGA-RUBIO, Elisa; \& YUBERO-JIMÉNEZ, Santiago (2018). Influencia de la resiliencia sobre la calidad de vida relacionada con la salud en adolescentes. Enfermería Clínica, 28(5), 283-291. https://doi.org/10.1016/j.enfcli.2018.06.003

STAVROU, Pilios-Dimitris; \& KOURKOUTAS, Elias (2017). School-Based Programs for Socioemotional Development of Children with or without Difficulties: Promoting Resilience. American Journal of Educational Research, 5(2), 131-137. http://pubs.sciepub.com/ education $/ 5 / 2 / 4$

STEINER, Riley; SHEREMENKO, Ganna; LESESNE, Catherine; DITTUS, Patricia; SIEVING, Renee; \& ETHIER, Kathleen (2019). Adolescent Connectedness and Adult Health Outcomes. Pediatrics, 144(7), e20183766. https://doi.org/10.1542/peds.2018-3766

STRATI, Anna; SCHMIDT, Jennifer; \& MAIER, Kimberly (2017). Perceived challenge, teacher support, and teacher obstruction as predictors of student engagement. Journal of Educational Psychology, 109(1), 131-147. https://doi.org/10.1037/edu0000108

TIAN, Lumei; LIU Lu; \& SHAN, Nan (2018) Parent-Child relationships and resilience among Chinese adolescents: The mediating role of self-esteem. Frontiers in Psychology. 9:1030. https://doi.org/10.3389/fpsyg.2018.01030

VAN HARMELEN, Anne-Laura; GIBSON, Jenny; ST CLAIR, Michelle; OWENS, Matt; BRODBECK, Jeannette; DUNN, Valerie; LEWIS, Gema; CROUDACE, T; JONES, Peter; KIEVIT, Rogier; \& GOODYER, lan (2016). Friendships and family support reduce subsequent depressive symptoms in at-risk adolescents. PLOS ONE, 11(5), e0153715. https://doi.org/10.1371/ journal.pone. 0153715

VILLALOBOS-PARADA, Boris; CARRASCO, Claudia; OLAVARRÍA, Dayana; ORTIZ, Sebastián; OYARZÚN, Denise; ASCORRA, Paula; AYALA, Álvaro; BILBAO, Ángeles; MORALES, Macarena; \& ÁLVAREZ, Juan Pablo (2016), Victimización de pares y satisfacción con la vida: la influencia del apoyo de profesores y compañeros de la escuela. Psykhe, 25(2), 116. https://doi.org/10.7764/psykhe.25.2.861

VILLALTA, Marco Antonio; DELGAdO, Ana Esther; ESCURRA, Luis Miguel; \& TORRES, William (2017). Resiliencia y rendimiento escolar en adolescentes de Lima y de Santiago de Chile de sectores vulnerables. Universitas Psychologica, 16(4), 1-11. https://doi.org/10.11144/ Javeriana.upsy16-4.rrea

WORSLEY, Joanne; MCINTYRE, Jason; \& CORCORAN, Rhiannon (2019). Cyberbullying victimization and mental distress: testing the moderating role of attachment security, 
social support, and coping styles. Emotional and Behavioural Difficulties, 24(10), 20-35. https://doi.org/10.1080/13632752.2018.1530497

YABLON, Yaacoov B.(2015). Positive school climate as a resilience factor in armed conflict zones. Psychology of Violence. 5(4), 393-401. https://doi.org/10.1037/a0039600

YABLON, Yaacoov B. (2019). School safety and school connectedness as resilience factors for students facing terror. School Psychology, 34(2), 129-137. https://doi.org/10.1037/ spq0000259 